\title{
RELATIONSHIPS IN TWO WORLDS, REAL AND VIRTUAL. CONTEXT OF MEANING AND HAPPINESS
}

In Happiness And Contemporary Society : Conference Proceedings Volume (Lviv, March, 20-21, 2021). Lviv: SPOLOM, 2021. P. 45-48. https://doi.org/10.31108/7.2021.7

ISBN 978-966-919-697-2

БОРЩЕВСЬКА Анжела, КИРИЛЮК Сергій

\section{СТОСУНКИ У ДВОХ СВІТАХ, РЕАЛЬНОМУ ТА ВІРТУАЛЬНОМУ. КОНТЕКСТ ОСМИСЛЕНОСТІ ТА ЩАСТЯ}

// Щастя та сучасне суспільство : збірник матеріалів міжнародної наукової конференції (Львів, 20-21 березня 2021 р.). - Львів : СПОЛОМ, 2021. С. 45-48. https://doi.org/10.31108/7.2021.7

ISBN 978-966-919-697-2 


\section{BORSHCHEVSKA Anzhela}

PhD, Associate Professors of the Department of Psychiatry and Psychotherapy FPGE Danylo Halytsky Lviv National Medical University (Lviv, Ukraine)

\section{KYRYLIUK Serhii}

PhD, Associate Professor of the Department of Psychiatry and Psychotherapy FPGE Danylo Halytsky Lviv National Medical University (Lviv, Ukraine)

\section{RELATIONSHIPS IN TWO WORLDS, REAL AND VIRTUAL. CONTEXT OF MEANING AND HAPPINESS}

We live in a world whose dynamics are dangerous on the one hand and attractive on the other. The intensity of communication and its diversity weaken the sense of spiritual connection with the Other. People increasingly prefer to build close relationships through the Internet and social networks. A new type of loneliness is formed than the one we felt in the "pre-gadget era". All human beings must take care of others. It makes life meaningful and gives a chance to feel happy.

Key words: relationships, happiness, meaningfulness, loneliness, virtualization

\section{БОРЩЕВСЬКА Анжела}

к. мед. н., доиент кафедри психіатрї̈ та психотерапії ФПДО

Львівський національний медичний університет ім. Данила Галицького (Львів, Україна)

\section{КИРИЛЮК Сергій}

к. мед. н., доцент кафедри психіатрії та психотерапії ФПДО

Львівський національний медичний університет ім. Данила Галицького

(Львів, Україна)

\section{СТОСУНКИ У ДВОХ СВІТАХ, РЕАЛЬНОМУ ТА ВІРТУАЛЬНОМУ. КОНТЕКСТ ОСМИСЛЕНОСТІ ТА ЩАСТЯ}

Тисячі свічок можна запалити від одної єдиної свічки, і життя іiї не стане коротше. Щастя не стає менше, коли ним ділишся.

(буддійська мудрість)

Ми часто буваємо більш самотні серед людей, ніж у тиші своїх кімнат... Ми живемо в тісноті і перечіплюємося один об одного і від цього, мені здається, трохи втрачаємо один до одного повагу.

Для справді важливого і сердечного спілкування така частота не потрібна (американський письменник Генрі Торо, XIX ст.) 
Сьогодні ми стикаємося 3 вкрай динамічним, нелінійним соціумом, описаним в категоріях «плинної сучасності» (3. Бауман), «Кінця сталості» (Е. Тоффлер) або «світу, який вислизає» (Е.Гідденс). Виникає ситуація втрати рівноваги між швидкістю соціальних трансформацій і швидкістю людської реакції, i це набуває характеру соціального стресу. Подібні зміни призводять до відмови від колишніх пріоритетів, до нового погляду на світ та до нового сприйняття соціального простору і соціального часу. Ритм сучасного життя не дозволяе озиратися назад так часто, як це було раніше. I людина опиняється в певному «режимі очікування ». Отже, ми живемо у світі, динаміка якого $з$ одного боку небезпечна, з іншого - приваблива. В такому контексті реалізація свого шансу для людини стає можлива лише при надзвичайній гнучкості і мобільності кожної дії людини. Людини як окремої, незалежної соціальної одиниці і як окремого вузла у величезній мережі стосунків.

Та інтенсивність комунікації та іiі різноспрямованість послаблюють відчуття духовного зв'язку з Іншим, і виявляється, що при такій високій частоті «зіткнень» єдино центральним суб'єктом для людини стає вона сама. Тому у світі поступово настає епоха пріоритету особистих інтересів, які при крайній динаміці, різноманітті і одночасно надзвичайній короткочасності міжособистісних відносин сприяють реалізації, ймовірно, найзаповітніших мрій людини - свободи 3 мінімальною відповідальністю. Та наше еволюційне завдання - бути разом. Нам необхідно створювати нові стосунки і розширювати коло своїх знайомств, щоб відчувати себе живими [2]. Всі людські істоти повинні піклуватися про інших і вносити свій вклад в життя інших людей. Це робить життя осмисленим, але це не обов'язково зробить нас щасливими. Емоція щастя відчувається тут і зараз, але швидко проходить, так само як й інші емоції. Позитивний вплив і почуття задоволення швидкоплинні. Осмисленість, навпаки, тривала. Вона з'єднує минуле 3 сьогоденням і майбутнім. В той час як «щастя взагалі не споглядає минуле або майбутнє. "Щастя не може здійснюватися, воно має настати. Потрібно мати причину, щоб бути щасливим» [1]. Щастя без сенсу характеризує достатньо неглибоке, егоцентричне або навіть егоїстичне життя, в якому все йде добре, потреби і бажання легко задовольняються, а всіх труднощів уникається. Так сьогодні, згідно 3 даними Центру з контролю і профілактики захворювань США, близько 4310 американців не виявили такої цілі в житті, яка б їх задовольняла. $40 \%$ людей, згідно цього дослідження, не бачать мети в своєму житті і ніяк до цього не відносяться. Ще чверть американців не відчуває, що саме наповнює їх життя сенсом.

Дослідження виявили, що у людей, що мають мету i сенс в житті, збільшується загальний добробут і задоволеність життям, поліпшується психічне і фізичне здоров'я, підвищується гнучкість, підвищується самооцінка, а також знижується ймовірність депресії. В той час як, лише прагнення до щастя,згідно досліджень, за іронією, робить людей менш щасливими. "Дуже сильне прагнення до щастя, ось що зриває щастя [1]. Щастя, за результатами опитувань, в тому, щоб відчувати себе добре. Зокрема, дослідники виявили, що щасливі люди схильні думати, що жити легко, вони знаходяться в хорошому фізичному стані, і вони в змозі купити те, чого хочуть. Щасливе життя також визначається відсутністю стресу або занепокоєння. Прагнення до щастя пов'язане з егоїстичною поведінкою "того, що бере", а не "дарувальника". Якщо у вас є потреба чи бажання - ви задовольняєте його, як голод, і це робить вас щасливим. Іншими словами, люди стають щасливими, коли отримують те, чого хочуть."Щасливі люди радіють, отримуючи вигоду від інших, а люди, що ведуть усвідомлене життя, отримують 
радість, коли віддають іншим" (Кетлін Вос). "В осмисленому житті ви використовуєте свої найсильніші сторони і таланти, щоби служити чомусь, на вашу думку, більшому, ніж ви самі " (Мартін Селигман). Наприклад, осмислене життя пов'язане з пртдбанням подарунків для інших, турботою про дітей. Люди, чиє життя осмислене, вклали себе в щось більше, ніж своє Его, тому в їх житті більше стресу і тривоги, ніж у щасливих людей.

Разом 3 тим, в усіх сферах суспільного життя можна спостерігати процес індивідуалізації, який зачіпає практично всі соціальні інститути. Все більше і більше стверджується незалежність у стосунках між батьками і дітьми, між подружжям. Цих відносин, як і усього суспільства, торкнулася невизначеність та нестійкість. Саме міжособистісна самотність стає наступною визначальною характеристикою сучасного життя. Багато хто відзначає парадоксальність цього явища. Адже 3 точки зору інтенсивності комунікації сучасність не мала рівних, і здається, що чим більше нас і чим інтенсивніше спілкування, тим далі ми від самотності. Але тут спрацював певний ефект зворотної реакції, коли в повсякденній суєті і нелінійності нашого життя ми розгубили один одного.

3 глобалізацією сучасного світу в наше життя увійшла і віртуалізація, тобто кіберпростір з безліччю соціальних мереж. Інтенсивність відносин між людьми зросла, але ми опинилися в ситуації «глобального села» (Marshall McLuhan, 1962), тобто зворотного процесу «стиснення» світу до малих розмірів, коли здається, що всі вже один одного знають. Це знання - особливе,специфічне. Система технологій, соціальні мережі стали полем самопрезентації, при якій людина має можливість активно створювати власний, багатогранний віртуальний проект, доступний всім [3].

Соціальний психолог з Массачусетського технологічного інституту і автор книги «Самотні разом: чому ми очікуємо більшого від технологій, ніж один від одного» Шеррі Таркл (Sherry Turkle) більше двадцяти років вивчає проблему відносин людини і технологій. Висновки, до яких вона прийшла, невтішні : люди все більше надають перевагу вибудові близьких стосунків за допомогою інтернету і соцмереж. В результаті, утворюється новий тип самотності, більш глибокий та безнадійний, ніж та самотність, яку ми відчували раніше, в «догаджетову епоху». Технології потрібні там, де ми найбільш уразливі. А ми вразливі. Ми самотні, але ми боїмося близькості. Тому ми розробляємо технології - від соціальних мереж до соціальних роботів, - які створять ілюзію спілкування, не вимагаючи дружбу натомість. Ми звертаємося до технологій, щоб відчути зв'язок, яким легко керувати. Ми сподіваємося, що за допомогою технологій зможемо підтримувати спілкування і в той же час бути незалежними від нього.

Професор Таркл впевнена, що успіх технологій, що змінюють наші уми i серця, обумовлений тим, що сучасні девайси пропонують нам «три фантазії, які зачаровують». По-перше, це відчуття, що можемо концентрувати увагу на тому, що цікаво, і контролювати те, що хочемо. Коли я питаю «Що не так $з$ живим спілкуванням?», коментує професор Таркл, «мені відповідають: Розмовляти доводиться в реальному часі і тому неможливо контролювати те, що скажеш». Отже, суть у тому що повідомлення, електронна пошта, пости - все це дозволяє нам бути такими, якими ми хочемо бути. Ми можемо редагувати, тобто ретушувати обличчя, голос, плоть, тіло.

По-друге, надію, що нас завжди почують. Люди настільки звикають обманювати себе і не розмовляти по-справжньому, звикають до меншого, що вони вже майже готові обходитися зовсім один без одного. Наприклад, багато хто 
ділиться бажанням, що коли-небудь більш просунута версія Сірі, цифрового помічника на Apple iPhone, стане кращим другом, який буде слухати, коли інші відвернуться. Напевно, таке бажання відображає гірку правду щодо того, що відчуття, що хтось слухає, дуже важливе для людей. Ось чому їм так подобається заводити сторінки у Facebook чи інших мережах - там же так багато автоматичних слухачів. I це значиме відчуття, що нас хтось слухає, змушує нас проводити час 3 машинами, які, як нам здається, піклуються про нас.

По-третє, помилка, що ми ніколи не будемо самотні. Відчуття самотності це проблема, яку потрібно вирішувати. I люди намагаються розв'язати цю проблему за допомогою зв'язку (у віртуальному світі). Але в цьому випадку зв'язок - це скоріше симптом, ніж ліки. Він акцентує, проте, не вирішує основну проблему. Людина починає вірити, що постійний зв'язок зробить їі менш самотньою. Але небезпека в тому, що насправді, це означає зворотне. Якщо ми не можемо існувати наодинці, ми стаємо більш самотні [4]. Зрештою, уява, творчість, духовне зростання - всі ці великі речі вимагають від нас усамітнення. I якщо на одній чаші терезів лежить девайс 3 десятками повідомлень без відповіді від мало знайомих людей, а на іншій чаші - ці скарби життя, людина може зробити вибір та віднайти баланс. Живучи з людьми, не забувай того, що ти дізнався у самоті. У самоті обмірковуй те, що дізнався зі спілкування з людьми (Лев Толстой).

Існує рівняння Дирака і воно найкрасивіше 3 усіх у фізиці. Воно описує феномен квантової заплутаності, в якому говориться: «Якщо дві системи взаємодіють одна 3 одною протягом певного періоду часу, а потім відокремлюються одна від одної, ми можемо описати їх як дві різні системи, але вони вже існують як інша унікальна система. Те, що відбувається 3 одним продовжує впливати на іншого, навіть на відстані миль або світлових років». Це квантова заплутаність або квантовий зв'язок. Дві частинки, які в певний момент були пов'язані, зв'язані завжди. Не дивлячись на відстань між ними, навіть якщо вони знаходяться на протилежних кінцях Всесвіту, зв'язок між ними миттєвий. Те саме відбувається між двома людьми, коли їх пов'язує те, що можуть відчувати тільки живі істоти. Ми називаємо це щастям бути поруч.

Люди бувають по-справжньому щасливі зовсім не тому, що у них все $\epsilon$, а тому, що вони є один в одного.

\section{ЛІТЕРАТУРА}

1. Віктор Франкл [електронний ресурс, режим доступу 13.02.2021] https://www.facebook.com/groups/1699343616971737/permalink/27661980069529 $54 /$ ?sfnsn $=$ mo

2. Сабина Кулиева [електронний ресурс, режим доступу 13.02.2021] https://psychologies.today/chego-ya-xochu-ot-otnoshenij-i-chto-mne-nuzhno-nasamom-dele/

3. Карине Яралян. Социальные процессы в современном обществе и его ценностные ориентиры [електронний ресурс, режим доступу 13.02.2021] ResearchGate: 03K_Yaralyan_r-1533902789.pdf

4. https://monocler.ru/odinokie-vmeste-sherri-tarkl-o-tom-pochemu-myipredpochitaem-sotsseti-lichnomu-obshheniyu [електронний ресурс, режим доступу 13.02.2021] 